\title{
Socio-Economic Determinism and Climate Change
}

\author{
Jan-Erik Lane ${ }^{1^{*}}$ \\ ${ }^{1}$ Fellow with Public Policy Institute, Belgrade; Address: 10 Charles Humbert, 1205 Geneva; 559 A, \\ 3rd Floor, Thuya Street, 9th Quarter, Yangon, Myanmar \\ *Jan-Erik Lane, E-mail: janeriklane34@googlemail.com
}

Received: November 15, 2017 Accepted: November 20, 2017 Online Published: November 23, 2017

doi:10.22158/asir.v1n2p131 URL: http://dx.doi.org/10.22158/asir.v1n2p131

\begin{abstract}
The global warming problematic is in reality decided not by the UNFCCC or IPCC with its mastodon meetings. The decisive players are the states of the following BIG polluters of CO2: China, India, Indonesia, Brazil, Russia Mexico, South Korea, Canada, Australia and the US, despite the fact that its present government already has defected from the common pool regime, set up in Paris 2017, These countries together with international shipping and aviation are putting out more than 50\% of the CO2s. However, they are little interested, because they emphasize the policy-making of socio-economic development, either economic growth with rich countries or the "catch-up" strategy with poor or emerging economies. Resilience will decide which countries can support the consequences of climate change.
\end{abstract}

\section{Keywords}

greenhouse gases, CO2, methane emissions, decarbonisattion policy, international coordination

\section{Introduction}

Just before the start of the UN global environment reunion COP23 (6-13 November 2017) in Bonn, the study Climate Science Special Report: Fourth National Climate Assessment (USGCRP, 2017): was published in Washington, enquiring into the global warming consequences for especially the US but also the world. It recommends a combination of national and international policy-making to halt temperature rise, despite the fact that the US government is negative. We must then ask: Can decarbonisation policies be implemented or managed? I will suggest: NO.

All countries in the world have formed a Common Pool Regime (CPR) to save the atmosphere from more GHGs, focusing only upon the $\mathrm{CO} 2 \mathrm{~s}$. The global decarbonisation plan includes:

i) Halting the rise if CO2s by 2020 (GOAL I);

ii) Reducing the CO2s by $30-40 \%$ by 2030 (GOAL II);

iii) Complete decarbonisation by around 2075 (GOAL III); 
iv) Decentralised implementation under international oversight, financial support and technical assistance.

These are enormous goals, as only one country, Uruguay, is near GOAL I and GOAL II. Some countries have lately had stalling or even decreasing $\mathrm{CO} 2 \mathrm{~s}$, but many other still face an upward sloping curve.

\section{Global Predicament: Energy-Environment Conundrum}

The Greenhouse Gases (GHG) have strong anthropogenic sources, being linked with socio-economic development or economic growth via the consumption of energy generally, especially the burning of fossil fuels, use of cement and emission of methane from landfills, cows, microbes, etc. The UNFCCC has focused on halting $\mathrm{CO} 2 \mathrm{~s}$ and decreasing them in a gigantic decarbonisation policy globally in this century. $\mathrm{CO} 2$ emissions are closely connected with energy consumption, globally speaking. Projections for future energy augmentation in the 21st century are enormous, especially for Asia (EIA, BP, and IEA). Figure 1 displays developments since 1990.

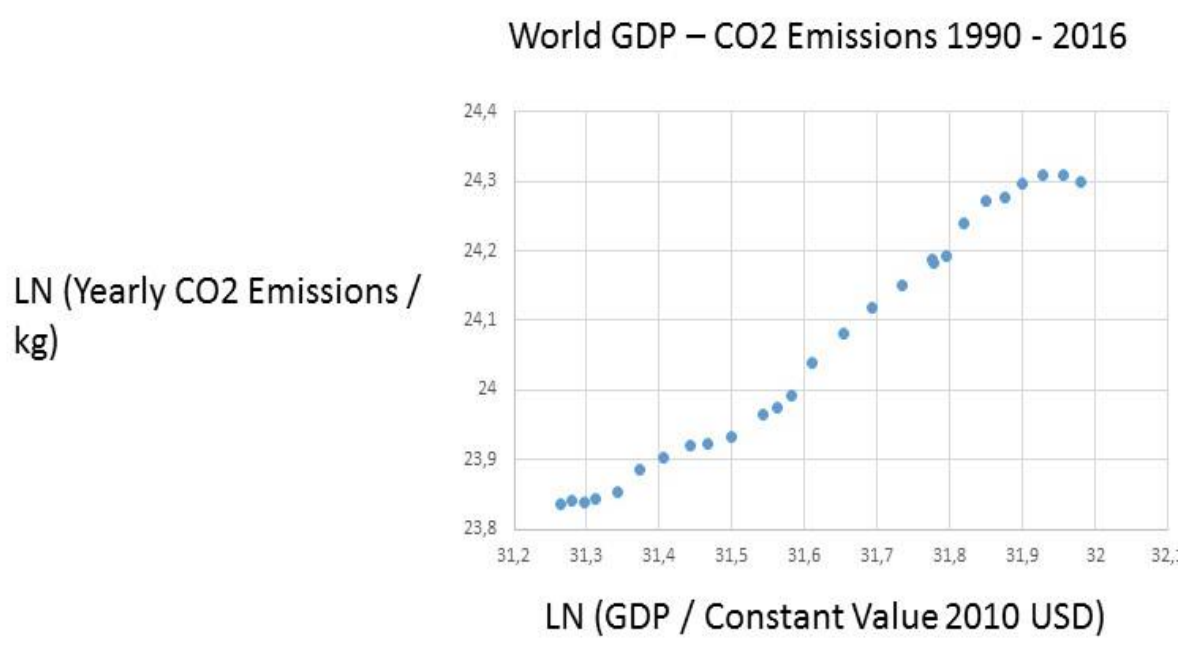

Figure 1. Global GDP-CO2 Link: $y=0,75 x ; R^{2}=0,98$

Source: See references.

There has been a widespread hope that the augmentation of $\mathrm{CO} 2$ s would "stall", but now China reports ominously that its $\mathrm{CO} 2 \mathrm{~s}$ are set to increase again. Thus, Figure 1 may lead to the planet not fulfilling GOAL I in 2020.

Burning fossil fuels is today essential for affluence and wealth, being vital to poor and rich countries. If energy consumption is reduced, we will have economic recession and mass poverty as well as of course unemployment writ large with social unrest. Planet Earth consumes simply far too much energy from burning the fossil fuels—-see Table 1. 
Table 1. Energy 2015 (Consumption in Million Tons of Oil Equivalent)

\begin{tabular}{lll}
\hline & Total & $\%$ \\
\hline Fossil fuels & 11306,4 & 86,0 \\
Oil & 4331,3 & 32,9 \\
Natural Gas & 3135,2 & 23,8 \\
Coal & 3839,9 & 29,2 \\
Renewables & 1257,8 & 9,6 \\
Hydroelectric & 892,9 & 6,8 \\
Others & 364,9 & 2,8 \\
Nuclear power & 583,1 & 4,4 \\
Total & 13147,3 & 100,0 \\
\hline
\end{tabular}

Source: BP Statistical Review of World Energy 2016.

Table 1 holds the answer to why GHG emissions have become the global headache number 1. Energy for humans and their social systems come to an average of $90 \%$ from burning fossil fuels: stone and wood coal, oil and gas. And people do that all over the world, though to very different degrees from $100 \%$ to less than $50 \%$ of all energy consumption, because it is necessary for affluence and survival.

\section{GHGs and Methane}

There are several types of GHGs, but the UNFCCC has concentrated upon the carbon dioxide particles $(\mathrm{CO} 2 \mathrm{~s})$. They are considered responsible for the human induced temperature rise that is global warming. It is true that the $\mathrm{CO} 2 \mathrm{~s}$ constitute the largest part of the GHCs. They are now stalling in some countries but far from all, not increasing any longer globally.

But halting the increase in $\mathrm{CO} 2 \mathrm{~s}$ is far from enough to halt global warming. As long as the countries in the world have large positive outflows of $\mathrm{CO} 2 \mathrm{~s}$, the risks of climate change augment. Consider further the immense $\mathrm{CO} 2 \mathrm{~s}$ from global transportations, which still increases with all the new flights and airports. CO2s are augmenting in for instance India, Indonesia, South Korea, Saudi Arabia, Brazil, Kazakhstan, etc. But why bypass methane? The UNFCCC has concentrated upon halting and reducing carbon dioxide, but now we are about to face a methane threat.

Methane emissions are now becoming more frequent and important for global warming. Thus, we have several greenhouse gases, but the two biggest are the $\mathrm{CO} 2 \mathrm{~s}$ and methane. Finally, we have the Nitrous Oxide and very small amounts of F-gases. Methane and F-gases are more powerful in preventing sun radiation to exit the Planet, but they are not as long lasting as the $\mathrm{CO} 2 \mathrm{~s}$. The oceans swallow much $\mathrm{CO} 2 \mathrm{~s}$, but this leads to acidification.

One may predict that methane emissions will increase significantly in the next decades, as the permafrost melts. Below is Florent Dieterlen's calculation of the rise of methane emissions (see papers by Lane \& Dieterlen, 2017). 


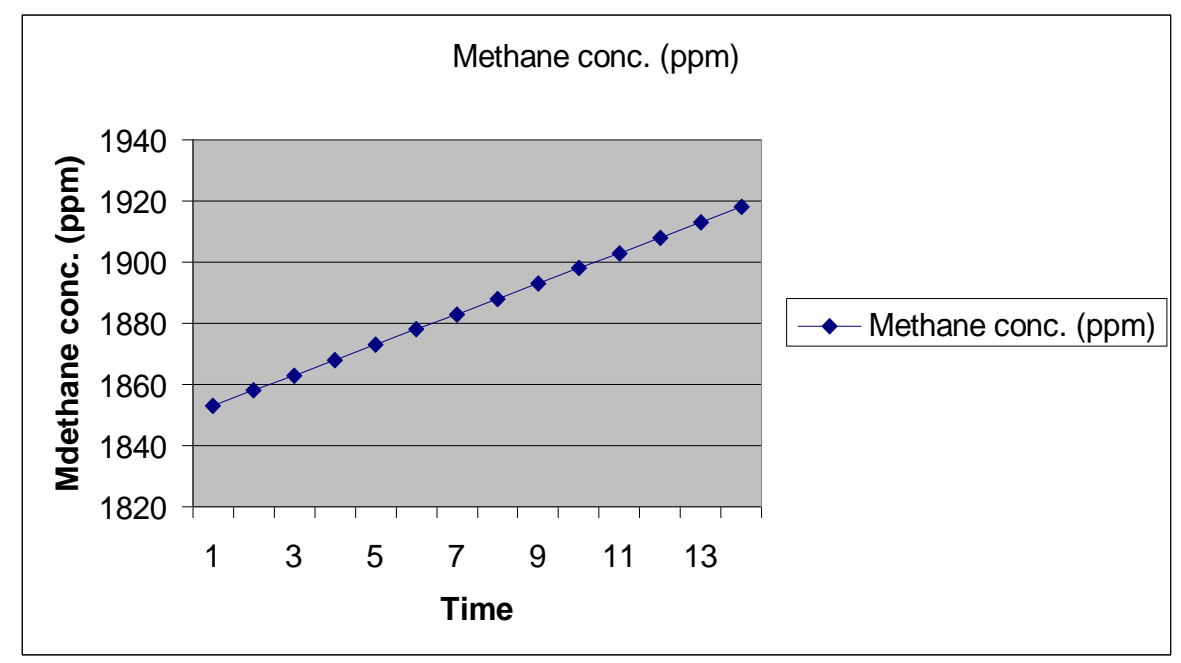

Figure 2. Methane Emissions in Dieterlen's Projection

Source: see references.

With methane emissions rising, it is all the more urgent to not only halt bot considerably reduce $\mathrm{CO} 2$ emissions. Can all nations do it? Probably not. Any decrease in methane concentration is improbable, i) Agriculture emissions increase with the increase of population, the increase in meat diet in developing countries and the temperature increasing the metabolism of microbes in rice agriculture;

ii) Wetlands emissions do not diminish with the microbial chemical activity on increase with temperature rise;

iii) Fossil fuel production and use do not diminish;

iv) Forests diminish in the tropics, resulting in a decrease in animal, vegetal and cultural (Indigenous People) assets;

v) Melting permafrost releases methane from land and see.

\section{Thirst for Energy: More Efficiency and Renewables}

GDP increases with the augmentation of energy per capita. Decarbonisation is the promise to undo these dismal links by making GDP and energy consumption rely upon carbon neutral energy resources, like modern renewables and atomic energy can this promise be kept or fulfilled? Figure 3 shows the almost iron law type link. 


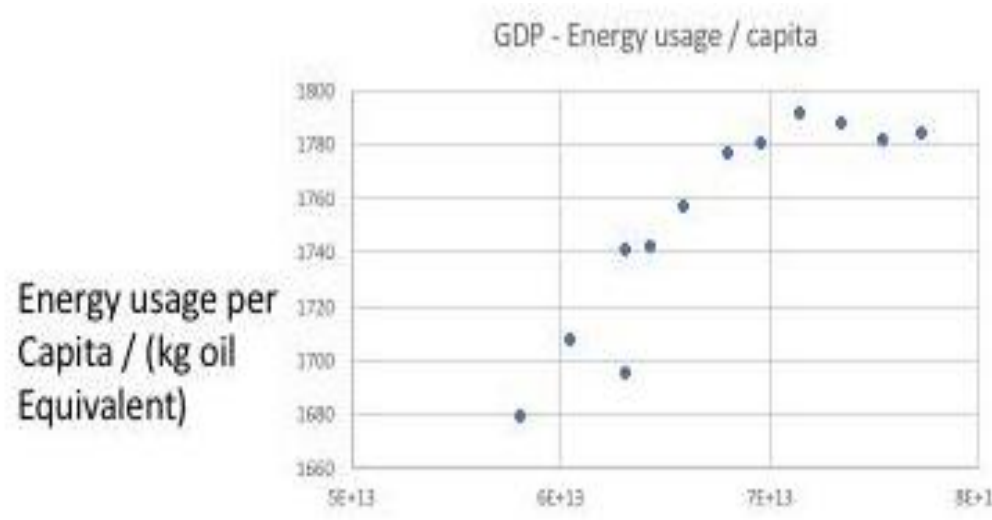

GDP / (Constant value 2010 USD)

Figure 3. GDP against Energy per Person, 2005-2016

Source: World Bank Data Indicators, data.worldbank.org; BP Statistical Review of World Energy 2017.

COP21 member country faces the dilemma in Figure 4: more energy gives higher economic growth but also more $\mathrm{CO} 2 \mathrm{~s}$. If countries continue to prioritize fossil fuels induced socio-economic development, they will bring about the Hawking irreversibility.

Energy per capita 2015 - CO2 emissions / capita 2016

$\mathrm{CO} 2$ emissions per capita 2016 / tonnes

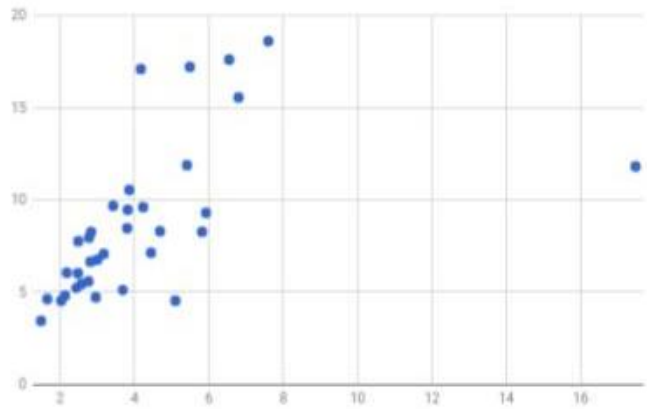

Energy use per capita 2015/ (tonnes oil equivalent)

Figure 4. Energy and CO2s per Capita

Sources: EU CO2 Database EDGAR: Co2 and GHG, http://www.edgar.jrc.ec.europa.eu/booklet2017/CO2_and_GHG_emissions_of_all_world_countries_bo oklet_online.pdf; World Bank Data indicators, http://www.data.worldbank.org

For saving the Planet and maintaining socio-economic development against poverty as well as economic growth for full employment, the economies of the world must become much better at energy efficiency. And they must turn massively to renewable energy sources now. 


\section{Kuznets' Curve for GDP and GHC? No}

In the general debate about environmentalism, the pro-economic growth argument states that increasing affluence will take care of the environmental problematic by itself: more wealth, more care for the environment. But Figure 5 shows that there is no Kuznets' curve (first rising with GDP, then descending with GDP) for $\mathrm{CO} 2$ : richer countries emit more $\mathrm{CO} 2$ than poor ones. International aviation is a very major source of $\mathrm{CO} 2$ emissions, and it is booming with augmenting GDP everywhere.

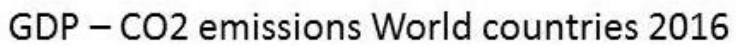

\section{$\mathrm{LN}$ ( Yearly CO2 emissions / kg)}

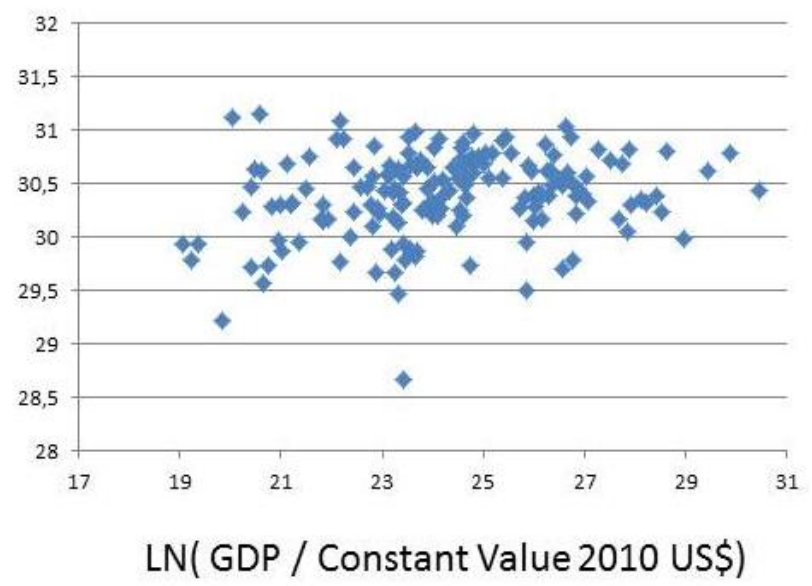

Figure 5. No Kuznets' Curve: GDP-CO2s

Source: see references.

\section{Decarbonisation Srategies}

The UNFCCC suggests a decentralized management strategy for decarbonisation. Reflecting the enormous differences in available energy resources in the member states of COP21 Treaty, each government must develop a strategy for achieving Goal I, Goal II and Goal III. The COP may wish to concentrate upon the following measures start credible decarbonisation:

1) Phasing out coal power plants by 2020; convincing a few countries like India and Australia not to build new ones;

2) Replace wood coal with natural gas stoves - small or large scale, stopping deforestation and the use of charcoal in households in poor nations;

3) Massive construction of solar power parks and wind power plants in all countries, as well as stimulate small scale solar power for households;

4) Turn some countries away from massive dam constructions towards solar power parks, like Brazil and India, as the environmental damages are too big and water shortages loom;;

5) Help some countries maintain their huge forests, like Brazil, Indonesia and Russia;

6) Abstain from expensive and unsafe carbon capture or sequestration techniques in favour of electricity: solar power and electrical vehicles. 
7) The promise of financial support-Super Fund-has to be clarified about both funding and budgeting. A management structure has to be introduced for oversight of the entire decarbonisation process. As the emissions of methane increase, the reduction of $\mathrm{CO} 2 \mathrm{~s}$ is all the more important.

8) The resort to atomic power plants is highly contested. Nuclear power gets safer and safer, but the problem of storing the used uranium has no solution. If global warming becomes really bad, all these radioactive materials could be released back in our social systems and nature. Some countries expand atomic energy, whereas others dismantle it. Germany and France should stop dismantling their atomic power stations and concentrate upon eliminating coal at one.

\section{Solarpower Parks—A Model Example}

Consider now Table 2, using the giant solar power station in Quarzazate as the benchmark—How many would be needed to replace the energy cut in fossil fuels and maintain the same energy amount, for a few selected countries with big $\mathrm{CO} 2$ emissions?

Table 2. Number of Ouarzazate plants necessary in 2030 for COP21's GOAL II

\begin{tabular}{|c|c|c|c|}
\hline Nation & $\begin{array}{l}\text { Co2 reduction pledge } \\
\text { / \% of } 2005 \text { emissions }\end{array}$ & $\begin{array}{l}\text { Number of gigantic solar } \\
\text { plants needed (Ouarzazate) }\end{array}$ & $\begin{array}{l}\text { Gigantic plants needed } \\
\text { for } 40 \% \text { reduction }\end{array}$ \\
\hline United States & 26-28 (Note 1$)$ & 2100 & 3200 \\
\hline China & None (Note 2) & 0 & 3300 \\
\hline EU28 & $41-42$ & 2300 & 2300 \\
\hline India & none (Note 2) & 0 & 600 \\
\hline Japan & 26 & 460 & 700 \\
\hline Brazil & 43 & 180 & 170 \\
\hline Indonesia & 29 & 120 & 170 \\
\hline Canada & 30 & 230 & 300 \\
\hline Mexico & 25 & 120 & 200 \\
\hline Australia & $26-28$ & 130 & 190 \\
\hline Russia & none (Note 3) & 0 & 940 \\
\hline Canada & 30 & 230 & 300 \\
\hline Mexico & 25 & 120 & 200 \\
\hline Iran & 4-12 (Note 4) & 22 & 220 \\
\hline Saudi Arabia & none (Note 2) & 0 & 150 \\
\hline Turkey & 21 & 60 & 120 \\
\hline Thailand & $20-25$ (Note 4$)$ & 50 & 110 \\
\hline France & 37 (Note 5) & 210 & 220 \\
\hline Italy & 35 (Note 5) & 230 & 270 \\
\hline Germany & 49 (Note 4 ) & 550 & 450 \\
\hline Argentina & none (Note 2) & 0 & 80 \\
\hline World & N/A & N/A & 16000 \\
\hline
\end{tabular}

Note. Average of 250-300 days of sunshine used for all entries except Australia, Indonesia, and Mexico, where 300-350 was used. 
If countries rely much upon water or geo-thermal power or atomic power, the number in Table 2 will be reduced. Table 2 displays the dependency upon fossil fuels that may go over $90 \%$ in some countries. Each country energy predicament is both situation dependent and path dependent, reflecting natural resources and past policies.

The key question is: Can so much solar power be constructed in some 10 years? If not, Hawking may be right. COP23 did not decide to embark upon an energy transformation of necessary colossal size. Solar power investments will have to take many things into account: energy mix, climate, access to land, energy storage facilities, etc. Geo-thermal power comes from volcanic power and sites.

It has been researched has much a climate of Canadian type impacts upon solar power efficiency. In any case, Canada will need back-ups for its many solar power parks, like gas power stations. Mexico has a very favourable situation for solar power, but will need financing from the Super Fund, promised in COP21 Treaty. In Latin America, solar power is the future, especially as water shortages from the Andes may be expected. Chile can manage their quota, but Argentine needs the Super Fund for sure. Uruguay has the best number globally, relying upon water and biomass.

\section{Conclusion}

The COP23 meeting of the UNFCCC resulted in basically NOTHING. It is NATO: no action, talk only. The COP21 Treaty states constitute a common pool club (CPR $=$ common pool regime) where each member country faces the dilemma in Figure 6: more energy gives higher economic growth but also more $\mathrm{CO} 2$ s. If countries continue to prioritize fossil fuels induced socio-economic development, they will defect in this CPR as in an ocean PD game and bring about Hawking irreversibility. Figure 6 displays the expansion of the various GHGs.

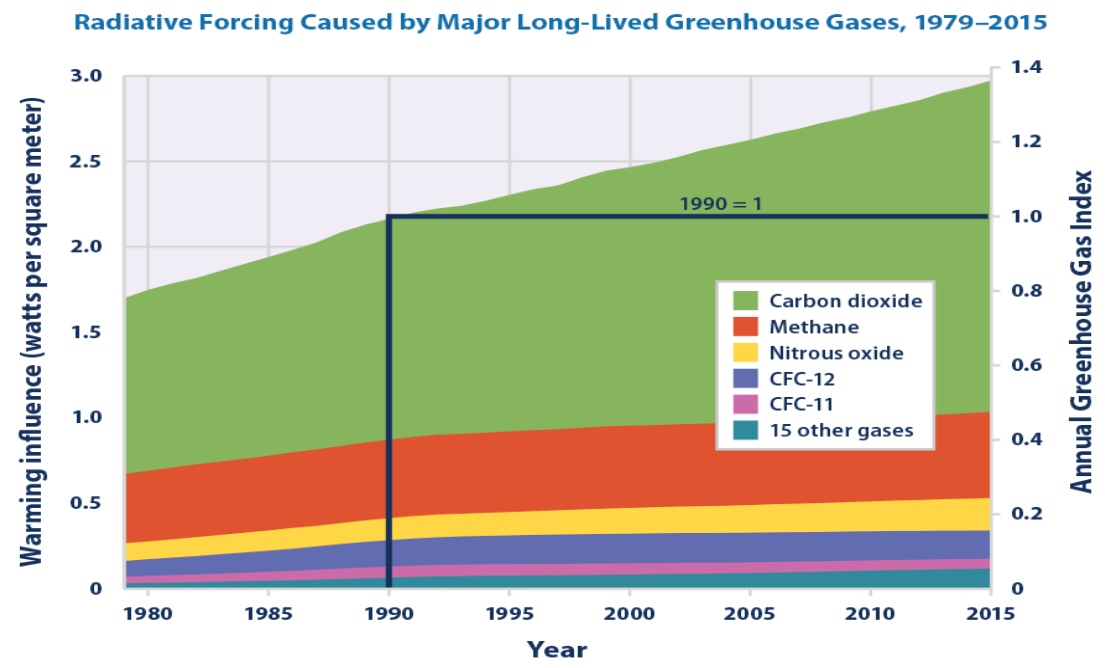

Figure 6. GHGs

Data Source: NOAA (National Oceanic and Atmospheric Administration), 2016. The NOAA Annual Greenhouse Gas Index. Retrieved June 2016, from http://www.esrl.noaa.gov/gmd/aggi 
Note. For more information, visit U.S. EPS's "Climate Change Indicators in the United States" at http://www/epa.gov/climate-indicators

States will have to rely upon resilience, but not all countries are resilient. In the long tun, no nation can withstand climate change, however resilient.

\section{Sources: Solar Power}

Paris. (2015). Tracking country climate pledges. Carbon Brief. Retrieved from https://www.carbonbrief.org/paris-2015-tracking-country-climate-pledges

CO2 Emission Reduction With Solar. (n.d.). Retrieved from http://www.solarmango.com/in/tools/solar-carbon-emission-reduction

EDGAR v 4.3.2, European Commission, Joint Research Centre (JRC)/PBL Netherlands Environmental Assessment Agency. (2016, forthcoming). Emission Database for Global Atmospheric Research (EDGAR), release version 4.3.2. Retrieved from http://www.edgar.jrc.ec.europe.eu

\section{GDP sources:}

OECD National Accounts data files. (n.d.).

World Bank national accounts data. (n.d.). Retrieved from http://www.data.worldbank.org

\section{GHG and energy sources:}

BP Energy Outlook 2016. (n.d.).

British Petroleum Statistical Review of World Energy 2016. (n.d.).

Energy Information Administration. (n.d.). Washington, DC.

EU Emissions Database for Global Research EDGAR. (n.d.). Retrieved from http://www.edgar.jrc.ec.europa.eu/

EU Joint Research Centre Emission Database for Global Atmospheric Research. (n.d.). Retrieved from http://www.edgar.jrc.ec.europa.eu/overview.php

International Energy Agency. (n.d.). Paris.

UN Framework Convention on Climate Change. (n.d.). Retrieved from http://www.unfccc.int/ghg_data/ghg_data_unfccc/time_series_annex_i/items/3814.php

World Bank Data Indicators. (n.d.). Retrieved from http://www.data.worldbank.org World Resources Institute CAIT Climate Data Explorer. (n.d.). Retrieved from http://www.cait.wri.org

\section{References}

Barro, R. J. (1991). Economic Growth in a Cross Section of Countries. The Quarterly Journal of Economics, 106(2), 407-443. https://doi.org/10.2307/2937943

Barro, R. J., \& Xavier, X. Sala-i-Martin. (1995). Economic Growth. McGrow Hill.

Barro, R. J., \& Xavier, X. Sala-i-Martin. (1992). Convergence. Journal of Political Economy, 100(2), 223-251. https://doi.org/10.1086/261816 
Conka, K. (2015). Un Unfinished Foundation. The United Nations and Global Environmental Governance. Oxford: OUP. https://doi.org/10.1093/acprof:oso/9780190232856.001.0001

Kaya, Y., \& Yokoburi, K. (1997). Environment, energy, and economy: Strategies for sustainability. Tokyo: United Nations University Press.

Ostrom, E. (1990). Governing the Commons. Cambridge: Cambridge U.P. https://doi.org/10.1017/CBO9780511807763

Ramesh, J. (2015). Green Signals: Ecology, Growth and Democracy in India (2015). Oxford : Oxford University Press. https://doi.org/10.1093/acprof:oso/9780199457526.001.0001

Rostow, W. W. (1960). The Stages of Economic Growth: A Non-Communist Manifesto. Cambridge: Cambridge University Press.

Sachs, J. D. (2015). The Age of Sustainable Development. New York: Columbia University Press. https://doi.org/10.7312/sach17314

Stern, N. (2007). The Economics of Climate Change. Oxford: OUP. https://doi.org/10.1017/CBO9780511817434

Stern, N. (2015). What are we waiting for? Cambridge, MA: MIT Press.

Vogler, J. (2016). Climate Change in World Politics. Basingstoke: Macmillan Palgrave. https://doi.org/10.1057/9781137273413

\section{Notes}

Note 1. The United States has pulled out of the deal.

Note 2. No absolute target.

Note 3. Pledge is above current level, no reduction.

Note 4. Upper limit dependent on receiving financial support.

Note 5. EU joint pledge of 40\% compared to 1990. 